Pena Justisia: Media Komunikasi dan Kajian Hukum
Vol. 17 No. 2, 2017, 17-28
Artikel Hasil Penelitian

\title{
Paradigama Peradilan Agama Sebagai Peradilan Bagi Umat Muslim Di Indonesia
}

\author{
Rahadi Wasi Bintoro
}

Fakultas Hukum Universitas Jenderal Soedirman, Indonesia

Artikel Diterima:

13 November 2017

Artikel Disetujui:

29 November 2017

Artikel Diterbitkan:

15 Desember 2017

\section{Abstract}

Competence of religious courts increasingly complex, but the more questionable also about the existence of Islamic personality as a principle inherent in the Religious Court. Therefore this paper discusses the paradigm of Islamic personality in Religious Court. In order to analyze this issue then used the historical approach and conceptual approach. Based on the analysis, the existence of religious court is directly proportional to the needs of Muslims and rulers in this country. Nevertheless, the Islamic personality has not been fully applicable to the religious court, since it is not yet clear that the policymakers to provide competencies that were previously the competence of other courts.

Keywords: Islam, Islamic law, Islamic personality

\section{Abstrak}

Kompetensi peradilan agama semakin kompleksnya, namun semakin dipertanyakan pula eksistensi personalitas keislaman sebagai prinsip yang melekat pada Peradilan Agama. Oleh karenanya tulisan ini membahas tentang paradigma personalitas keislaman di peradilan Agama. Dalam rangka menjawab permasalahan tersebut maka digunakan pendekatan historis dan konseptual. Berdasar analisis, eksistensi peradilan agama berbanding lurus dengan kebutuhan umat Islam dan pihak yang berkuasa di negeri ini. Namun demikian, personalitas keislaman belum dapat melekat seutuhnya pada peradilan agama, karena belum legowonya pengampu kebijakan untuk menyerahkan kompetensi yang sebelumnya menjadi kompetensi peradilan lain.

Kata kunci: Agama Islam, Hukum Islam, Personalitas Keislaman 
18 Pena Justisia: Media Komunikasi dan Kajian Hukum

Vol. 17, No. 2, 2017

\section{PENDAHULUAN}

Tahun 2006 dipandang sebagai tahun revolusioner bagi Peradilan Agama, sebagai akibat semakin luasnya kompetensi Peradilan Agama melalui UU No. 3 tahun 2006. Sebagaimana diketahui, berkaitan dengan substansi hukum, Peradilan Agama selama orde baru hanya memiliki kompetensi untuk menyelesaikan sengketa dalam bidang hukum keluarga (al-aḥwal al-shaḥsiyah), seperti soal perkawinan, kewarisan, wasiat, dan hibah, yang dilakukan berdasarkan hukum Islam, serta wakaf dan shadaqah. ${ }^{1}$ Kemudian UU No. 7 Tahun 1989 diubah melalui UU No. 3 Tahun 2006, dimana terdapat penambahan kompetensi meliputi zakat, infaq dan ekonomi syariah. Dengan demikian maka semakin kompleks lah kompetensi absolut yang dimiliki Peradilan Agama.

Perubahan UU No. 3 Tahun 2006 tidak lepas dari dinamika penerapan ekonomi syaria di dunia dan di Indonesia. Sistem ekonomi syariah tumbuh dengan pesat pada awal 1970-an² dan terus berkembang ${ }^{3}$ sampai saat ini. Ekonomi Syariah adalah satu kesatuan tak terpisahkan dengan ajaran Islam yang komprehensif dan universal, sifat dan cakupannya yang luas serta fleksibel khususnya di bidang mu'amalah sehingga dapat diterapkan pada setiap komunitas termasuk non muslim. ${ }^{4}$ Salah satu pioner dari berjalannya sistem ekonomi syariah di Indonesia dapat dilihat dari perkembangan perbankan syariah sebagai bagian dari sistem ekonomi syariah sejak tahun 1998 sampai dengan sekarang. Perkembangan lembaga ekonomi syariah, seperti perbankan syariah, asu-

1 Lihat Pasal 49 ayat (1) UU No. 7 Tahun 1989 tentang Peradilan Agama

2 Mehmet Asutay, "Conceptualisation of The Second Best Solution In Overcoming the Social Failure of Islamic Banking and Finance: Examining the Overpowering of Homoislamicus By Homoeconomicus", IIUM Journal of Economics and Managemen, Vol. 15, No. 2, 2007, The International Islamic University Malaysia, hlm. 168, PP: 167-195; M. Raquibuz Zaman and Hormoz Movassaghi, Islamic Banking a Performance Analysis ", The Journal of Global Busi-ness, Vol. 12, No. 22, Spring 2001, hlm. 38. Pp. 31-38

3 Munawar Iqbal And Philip Molyneux, "Thirty Years Of Islamic Banking:History, Performance And Prospects", Reviewed by : Abdelkader Chachi, Islamic Economics Research Centre King Abdulaziz University, Jeddah, Saudi Arabia. J. KAU: Islamic Econ., Vol.19, No. 1, hlm. 37, pp: 37-39; M. Kabir Hassan and Abdel-Hameed M. Bashir, "Determinants of Islamic Banking Profitability", Papers, 10th ERF Annual Conference, Morocco, 2003, web: ransi syariah, gadai syariah, dan lain-lain cukup pesat beberapa tahun terakhir ini di Indonesia. ${ }^{5}$

Perkembangan sistem ekonomi syariah ditandai dengan menjamurnya kegiatan-kegiatan usaha dengan prinsip Syariah ini menimbulkan implikasi hukum pada pola penyelesaian sengketanya, khususnya di pengadilan, mengingat penyelesaian sengketa ekonomi syariah belum diatur dalam UU No. 7 Tahun 1989 tentang Peradilan Agama. Oleh karenanya pada tahun 2006 dilakukan perubahan terhadap undang-undang tersebut melalui UU No. 3 tahun 2006 dan untuk menyesuaikan dengan uu kekuasaan kehakiman, undang-undang peradilan Agama diperbaharui lagi pada tahun 2009 melalui UU No. 50 tahun 2009.

Semakin kompleknya kompetensi Peradilan Agama merupakan wujud keinginan masyarakat muslim indonesia untuk menerapkan hukum Islam secara kaffah, sekalipun masih terbatas pada bidang tertentu. Sebagaimana tertuang dalam ketentuan pasal 1 UU No. 50 tahun 2009 bahwa Peradilan Agama adalah peradilan bagi orangorang yang beragama Islam, kemudian Pasal 2 UU No. 3 tahun 2006 bahwa Peradilan Agama adalah salah satu pelaku kekuasaan kehakiman bagi rakyat pencari keadilan yang beragama Islam mengenai perkara tertentu. Ketentuan ini merupakan perluasan dari ketentuan sebelumnya pada UU No. 7 tahun 1989 bahwa Peradilan Agama merupakan salah satu pelaksana kekuasaan kehakiman bagi rakyat pencari keadilan yang beragama Islam mengenai perkara perdata tertentu yang diatur dalam Undang-undang ini. Perubahan frase "per-

http://nzibo.com/IB2/Determinants. pdf, Diakses pada tanggal 11 Desember 2014; Mardani, "Kedudukan Hukum Islam dalam Sistem hukum Nasional”, Jurnal Hukum, Vol. 16 No. 2, April 2009, hlm. 282.Pp. 267-287.

4 Ahmad, "Penyelesaian Sengketa Ekonomi Syariah di Pengadilan Agama”, Jurnal Ius, Vol. 2 No. 6, Desem-ber 2014, hlm. 476, Pp. 476-488.

5 Muhammad Syafi'i Antonio, "Membangun Ekonomi Islam di Indonesia", Varia Peradilan, Tahun XXI No. 245 April 2006, Jakarta: IKAHI, hlm. 25; Ali Mansyur, "Aspek Hukum Perbankan Syariah dan Implementasinya di Indonesia", Jurnal Dinamika Hukum, Vol. 11 Edisi khusus, 2011, Purwokerto: Fakultas Hukum Universitas Jenderal Soedirman, hlm. 69; Tim Lindsey, "Between Piety and Prudence: State Syariah and the Regulation of Islamic Banking in Indonesia", Sydney Law Review, Vol. 34 No. 107, 2012, Sydney: Sydney Law School the University of Sydney, hlm. 111 
kara perdata tertentu" menjadi "perkara tertentu" membawa implikasi yang luas. Hal ini disebabkan, selain perkara perdata maka Peradilan Agama dimungkinkan memeriksa perkara pidana. Perubahan ini disebabkan adanya keinginan masyarakat muslim tertentu untuk secara kaffah menerapkan hukum Islam dalam peri kehidupannya. Sebagaimana diketahui, perluasan makna pada "perkara tertentu" telah membawa implikasi penguatan penerapan syariah bagi masyarakat di Daerah Istimewa Aceh, sehingga UU No. 3 tahun 2006 memperkuat landasan hukum Mahkamah Syar'iyah dalam melaksanakan kewenangannya di bidang jinayah berdasarkan qanun. Dengan demikian peradilan agama adalah peradilan Islam bagi umat Islam, inilah yang kemudian disebut sebagai prinsip personalitas keislaman. Prinsip personalitas keislaman merupakan ciri khas dari peradilan agama yang tidak dimiliki peradilan lain. Frase "perkara tertentu" juga berhubungan dengan kompetensi absolut sebagaimana diatur dalam Pasal 49 UU No. 3 Tahun 2006 bahwa Pengadilan Agama bertugas dan berwenang memeriksa, memutus, dan menyelesaikan perkara di tingkat pertama antara orang-orang yang beragama Islam di bidang: perkawinan; waris; wasiat; hibah; wakaf; zakat; infaq; shadaqah; dan ekonomi syariah.

Kompetensi yang relatif baru adalah ekonomi syariah, dikatakan baru karena sampai saat ini masih belum ada "kesepakatan" penyelesaian ekonomi syariah yang berkepastian hukum. Pelimpahan kewenangan memeriksa, memutus dan menyelesaikan perkara ekonomi syariah kepada Peradilan Agama sampai saat ini masih menyisakan polemik, tidak hanya di kalangan akademisi dan praktisi hukum, tetapi juga praktisi dalam lapangan ekonomi syariah, khususnya dalam bidang perbankan dan lembaga pembiayaan. Hal ini disebabkan pengaturan mengenai ekonomi syariah tidak serinci seperti kewenangan pengadilan agama lainya, seperti perkawinan. Pengaturan bidang perkawinan atau lainnya lebih rinci, sehingga dapat memudahkan hakim menguji perkara yang diajukan kepadanya termasuk dalam batasan kewenangannya atau tidak. Padahal ekonomi Syariah termasuk masalah yang komplek dan tidak mudah, serta berkembang sangat pesat, yang dapat membuka ruang serta memungkinkan siapa saja bisa terlibat didalamnya. Sehingga tidak jarang dijumpai "perkara ekonomi syariah" tetapi diputus di pengadilan negeri yang berada di bawah lingkup Peradilan Umum. Kondisi ini tentu saja menimbulkan ketidakpastian hukum dalam penegakkannya.

\section{PERMASALAHAN}

Berdasarkan uraian tersebut, maka isu hukum yang diangkat dalam tulisan adalah paradigama personalitas keislaman di peradilan agama.

\section{METODE PENELITIAN}

Tulisan ini disusun dengan menggunakan tipe penelitian normatif dengan pendekatan historis dan konseptual atas berlakunya Peradilan Agama bagi umat muslim di Indonesia. Sebagai sumber bahan hukum primer adalah peraturan perundang-undangan yang berhubungan dengan Peradilan Agama dan bahan hukum sekunder terdiri dari buku-buku teks, hasil penelitian hukum, jurnal-jurnal hukum, dan hasil simposium mutakhir yang berkaitan dengan obyek penelitian. Sumber bahan hukum tersebut dikumpulkan dengan metode kepustakaan dan dokumenter kemudian dianalisis secara kualitatif dengan cara menginterpretasikan dan mendiskusikan bahan hasil penelitian berdasarkan pada asas-asas hukum, teoriteori hukum, pengertian hukum, norma hukum, serta konsep yang berkaitan dengan pokok permasalahan.

\section{PEMBAHASAN}

Terbentuknya Peradilan Agama seperti sekarang ini tidak bisa terlepas dari proses sejarah penyelesaian sengketa atau perkara yang muncul di masyarakat pada masa awal Islam berkembang di Indonesia. Sejarah Lembaga Peradilan Agama di Indonesia sebagai salah satu pelaksana kekuasaan kehakiman telah cukup memakan waktu yang sangat panjang, sepanjang agama Islam itu sendiri 
eksis di Indonesia. ${ }^{6}$ Dikatakan demikian, karena memang Islam adalah merupakan agama hukum yaitu sebuah aturan yang mengatur manusia dengan Allah Yang Maha Esa (habluminallah) yang sepenuhnya dapat dilaksanakan oleh pemeluk agama Islam secara pribadi (person), juga mengandung kaidah-kaidah yang mengatur hubungan manusia dengan manusia lain (habluminannas) dan berada dalam kehidupan masyarakat yang memerlukan bantuan penyelanggara negara untuk melaksanakannya secara paripurna. ${ }^{7}$

Peradilan Agama sebagai peradilan Islam di Indonesia merupakan salah satu institusi Islam yang sangat tua yang telah mengalami pasang surut. ${ }^{8}$ Peradilan Agama pada dasarnya telah ada jauh sebelum Indonesia merdeka, bahkan ada yang menyebutkan pada abad ke tujuh atau kedelapan Masehi, ${ }^{9}$ sesuai dengan tingkat dan bentuknya sebagaimana ditentukan oleh Hukum Islam. Pelaksanaan ajaran agama Islam, pada mulanya belum terbentuk sebagai pranata masyarakat yang teratur dan sistematis, namun kemudian karena kebutuhan masyarakat akan pengembangan ajaran dan implementasinya dalam masyarakat, maka kemudian tatananya berkembang sebagaimana masyarakat Islam seperti sekarang ini. ${ }^{10}$

Peradilan Islam pada mulanya berbentuk Tahkim, yakni; suatu penyerahan kepada seseorang Muhakkam untuk memberikan keputusan atas suatu persoalan/sengketa. Muhakim dipilih secara langsung oleh para pihak yang bersengketa secara musyawarah melalui ba'it Ahlul Hilli wa Aqdli, yaitu pengangkatan atas seseorang yang dipercaya oleh majelis atau kumpulan orangorang terkemuka dalam masyarakat seperti kepala suku atau kepala adat dan lain-lain. Perkembangan selanjutnya, Islam sebagai agama dan hukum semakin mengakar dan dominan mewarnai

6 Muhammad Amin Suma, Himpunan Undang-undang Perdata Islam dan Peraturan Pelaksanan Lainnya di Negara Hukum Indonesia, Jakarta: Rajawali Press, 2004, hlm. 57

7 Ibid.

8 Sumadi Matrais, "Kemandirian Peradilan Agama dalam Perspektif Undang-undang Peradilan Agama", IUSTUM, No. 1 Vol. 15, Januari 2008, hlm. 121-124

9 Ahmad R, "Peradilan Agama di Indonesia". Yudisia. Vol. 6 No. 2. 2015, hlm. 312.

10 Hamka, Sejarah Umat Islam, Jilid III, Bulan Bintang, Jakarta, 1981, hlm. 35 seluruh kehidupan sebagian besar bangsa Indonesia. ${ }^{11}$ Kenyataan ini mulai berlaku sejak Islam ditetapkan sebagai agama resmi pada Kerajaan Demak sekitar abad lima belas.

Kemudian di beberapa daerah di Indonesia seperti sultan-sultan di Aceh, Pagaruyung, Bonjol, Pajang, Banjar, Pasai dan lain-lain memberlakukan Islam sebagai agama resmi dan hukum negaranya. Puncak dominasi Islam ini berlaku pada zaman Kerjaaan Mataram di tangan Sultan Agung sekitar tahun $1750 \mathrm{M}$, yang memberlakukan hukum Islam secara total $100 \%$ baik pidana maupun perdata. ${ }^{12}$ Bentuk peradilannya pun sudah tidak lagi berbentuk Tahkim seperti awal-awal pemelukan Islam, melainkan sudah meningkat kepada bentuk peradilan (qadla), pada masa itu kemudian lahir lembaga seperti Sidang Jumat, Rapat Ulama, Rapat Agama maupun Mahkamah Syara' dan Soerambi, yang istilah-istilah itu tak lain sebagai Peradilan Agama yang kita kenal sekarang ini. ${ }^{13}$ Pengangkatan pengambilan sebuah keputusan atau hakimnya pun, sudah tidak lagi berdasarkan penunjukan langsung dari para pihak yang bersengketa atau pemilihan dan ba'it Ahulul wal Aqdli, melainkan sudah melalui pemberian Tauliyah (kekuasaan) dari Ulil Amri (Pemerintah dan Penguasa). Kemudian lahirlah peraturan-peraturan adat dan Swapraja maupun peraturan-peraturan Sultan atau Raja sebagai dasar keberadaannya. ${ }^{14}$ Istilah-isilah seperti Kanjeng Penghulu, Penghulu Tuanku Mufti maupun Tuanku Qadi, di samping raja-raja dan bupati dahulu, adalah penjelamaan dari watak dan kepribadian ketetanegaraan dari pelaksanaannya syariat Islam di Indonesia. ${ }^{15}$

Eksistensi peradilan Islam pun mengalami pasang surut pada masa penjajahan, khususnya pada masa penjajahan Belanda. Pemerintah Belanda, atas usul L.WC. Van Den Berg (1845-1927)

11 ASA, Sejarah Peradilan Agama, Serial Media Dakwah, Jakarta, Agustus 1989.

2 Ibid.

13 Ibid.

14 Marulak Pardede, Eksistensi dan Kedudukan Hukum Peradilan Agama Dalam Tata Hukum Indonesia, Angkatan Bersenjata, Jakarta, 24 Agustus 1989.

15 Departemen Agama RI, Laporan Bagian Proyek Penelitin Yusisprodensi Peradilan Agama, Proyek Peningkatan Penelitian/ Survey Keagamaan, Jakarta: 1971/1972, hlm. 71 
berdasarkan teorinya reception in complexu, bahwa hukum bagi orang Indonesia mengikuti agamanya, ${ }^{16}$ sehingga pada akhirnya Pemerintah Kolonial memberikan aturan secara formal dalam perundang-undangan yang lebih kontrit atas pelaksanaan Hukum Islam. Hal ini diwujudkan dalam Stbl. 1882 Nomor 152 tentang pembentukan Pengadilan Agama di Jawa dan Madura dengan nama Priesterrad. Sedangkan untuk daerah luar Jawa dan Madura masih diserahkan kepada peraturan-peraturan Adat maupun Swapraja. ${ }^{17}$

Namun kemudian C. Snouck Hurgronye, ahli Hukum Adat, mencetuskan teori baru yang sangat bertentangan dengan teori L.W.C. Van Den Berg, yaitu theori receptie. Teori Receptie menekankan bahwa sebenarnya yang berlaku di Indonesia adalah Hukum Adat asli, namun demikian hukum adat telah mendapat pengaruh dari hukum islam. Oleh karena itu, menurutnya, hukum Islam itu baru mempunyai kekuatan kalau dikehendaki dan diterima oleh hukum adat dan dengan demikian lahirlah dia sebagai hukum adat bukan sebagai hukum Islam. ${ }^{18} \mathrm{C}$. Snouck Hurgronye yang menduduki jabatan sebagai panasehat Pemerintah Hindia Belanda tentang soal-soal Islam dan anak negeri. Dia beranggapan bahwa keluarnya Stbl. 1882 Nomor 152 merupakan kesalahan yang patut disesalkan, karena Peradilan Agama ini seharusnya dibiarkan terus berjalan secara liar tanpa campur tangan Pemerintah, sehingga keputusan-keputusannya tidak perlu memperoleh kekuatan undang-undang. ${ }^{19}$ Atas desakan dan pengaruh C. Snouck Hurgronye dalam kedudukannya tersebut, secara sistematis, halus dan berangsur-angsur, hukum agama yang berlaku bagi orang Islam mulai diubah dan dipersempit ruang geraknya dalam kehidupan masyarakat, sehingga menimbulkan banyak reaksi dan kekecewaan pada benak masyarakat Islam. ${ }^{20}$

\footnotetext{
16 Sayuti Thalib, 1985, Receptio A Contrario, Bina Aksara, Ja karta, hlm. 5

17 A.Sukmawati Assaad, "Teori Pemberlakuan Hukum Islam di Indonesia", Jurnal Al Ahkam, Vol. IV No. 2, Agustus 2014, hlm. 30

18 Sayuti Thalib, Op.Cit., hlm.13
}

Pada awal kemerdekaan, Peradilan Agama tidak diakui sebagai lembaga pelaku kekuasaan kehakiman. Hal ini terbukti Undang-undang Nomor 19 Tahun 1948 yang mencabut Undang-undang Nomor 7 Tahun 1947 tentang Susunan dan Kekuasaan Mahkamah Agung dan Kejaksaan Agung hanya menyebut perangkat kekuasaan kehakiman meliputi Peradilan Umum, Peradilan Tata Usaha Pemerintah, dan Peradilan Ketentaraan. Namun demikian, undang-undang ini memberikan kesempatan terhadap perkara perdata antara orang Islam yang menurut hukum yang hidup harus diperiksa dan diputus menurut hukum agamanya, harus diperiksa dan diputus oleh Pengadilan Negeri, yang terdiri dari seorang Hakim yang beragama Islam, sebagai Ketua dan dua orang Hakim ahli agama Islam sebagai anggota, yang diangkat oleh Presiden atas usul Menteri Agama dengan persetujuan Menteri Kehakiman. ${ }^{21}$ Menyadari akan betapa pahit getirnya kehendak Undang-undang Nomor 19 Tahun 1948 eksistensi Peradilan Agama oleh umat Islam sebagai penduduk mayoritas di Indonesia, undang-undang tersebut tidak sampai diberlakukan. Untuk daerah-daerah yang secara de facto dikuasai oleh Pemerintah Republik Indonesa, pelaksanaan Peradilan Agama berdasarkan kepada ketentuan Pasal II Aturan Peralihan Undang-Undang Dasar 1945 masih didasarkan kepada Stbl. 1882 Nomor 152 jo. Stbl. 1937 Nomor 116 dan 610 untuk Jawa dan Madura. ${ }^{22}$ Dibeberapa tempat, untuk daerah-daerah yang dikuasai oleh tentara sekutu dan Belanda, telah didirikan pengadilan agama dengan nama Penghulu Gerechten sebagai pengganti Priesteraaden, sedangkan untuk pengadilan agama tingkat bandingnya, telah pula didirikan beberapa Majelis Ulama. Hal ini untuk mengimbangi Mahkamah Islam Tinggi yang telah dipindahkan ke Surakarta. ${ }^{23}$ Pasca penyerahan kekuasaan dari Pemerintahan Kolonial Belanda kepada Pemerintahan

\footnotetext{
19 Zaini Ahmad Noeh dan Abdul Basit Adnan, Sejarah Singkat Peradilan Agama Islam di Indonesia, Bina Ilmu, Surabaya, 1983., hlm. 34

20 Ibid.

21 Pasal 35 ayat (2) UU No. 19 Tahun 1948

22 Zaini Ahmad Noeh dan Abdul Basit Adnan, Op.Cit., hlm. 5455.

23 Departemen Agama RI, Laporan... Op.Cit., hlm. 33
} 
Republik Indonesia pada tanggal 27 Desember 1949, maka peraturan-peraturan tentang Penghulu Gerechten tersebut seperti Javaasche Caurant Nomor 32 Tahun 1946, Nomor 25 dan 39 Tahun 1949, Keputusan Recomba Jawa Barat Nomor Rechtspraak. WJ. 29. 27 Tahun 1948 dan lain-lainnya, dianggap tidak berlaku (terhapus) berdasarkan Peraturan Pemerintah Pengganti Undangundang Nomor 1 Tahun 1950 yang diganti oleh Undang-undang Nomor 8 Tahun 1950. Selanjutnya, Stbl. 1882 Nomor 152 jo. Stbl. 1937 Nomor 116 dan 610 dianggap tetap berlaku. ${ }^{24}$

Tahun 1951, melalui Penetapan Menteri Agama RI Nomor 1 Tahun 1951diadakan panataan terhadap pegawai Peradilan Agama, berupa pengangkatan para pegawainya menjadi Pegawai Negeri Sipil. Sehingga dengan demikian, mereka yang waktu jaman penjajahan tidak mendapat gaji, sekarang mendapatkannya secara tetap dari negara. Selain itu pengangkatan atas jabatan Ketua Pengadilan Agama beserta pegawai-pegawainya dan memberhentikannya menjadi wewenang Menteri Agama, tidak lagi merupakan wewenang Bupati atau Residen seperti halnya pada waktu jaman penjajahan. ${ }^{25}$

Dalam rangka unifikasi dalam bidang peradilan secara menyeluruh, kemudian dikeluarkan Undang-undang Darurat Nomor 1 Tahun 1951 tentang Tindakan Sementara Untuk Menyelenggarakan Kesatuan Susunan, Kekuasaan dan Acara pada Pengadilan Sipil. Dalam undang-undang tersebut, Pengadilan Adat dan Swapraja dihapuskan. Namun demikian, berdasar Pasal 1 ayat (2) dan (4) Undang-undang Darurat No. 1 Tahun 1951, bagi pengadilan agama yang berada dalam lingkungan Peradilan Adat dan Swapraja, jika ia merupakan bagian tersendiri dari badan peradilan tersebut (Adat dan Swapraja) tidak larut terhapus, dan sebagai kelanjutannya akan diatur oleh Peraturan Pemerintah, sebagai contoh Peraturan pemerintah No. 45 Tahun 1957 tentang Peraturan Tentang Pengadilan Agama di Luar Jawa-

\footnotetext{
Ibid

Ibid

Ibid. hlm. 34.
}

Madura. Peraturan Pemerintah ini memberikan landasan hukum yang kuat bagi eksistensi Peradilan Agama di daerah-daerah diluar Jawa dan Madura serta sebagian Kalimantan Selatan. Berdasarkan Peraturan Pemerintah tersebut, maka Menteri Agama mengeluarkan Penetapannya Nomor 58 Tahun 1957 tentang Pembentukan 54 Pengadilan Agama/ Mahkmah Syariah dan 4 Pengadilan Agama/ Mahkmah Syariah Provinsi untuk daerah Sumatera. Kemudian disusul dengan pembentukan Pengadilan Agama/ Mahkmah Syariah di Indonesia Bagian Timur dengan Pengadilan Agama/ Mahkamah Syariah Provinsi di Banjarmasin dan Ujung Pandang (Makassar). ${ }^{26}$

Kemudian pada tahun 1969 dikeluarkan UU No. 6 tahun 1969 tentang Pernyataan Tidak Berlakunya Berbagai Undang-Undang Dan Peraturan Pemerintah Pengganti Undang-Undang. Undang-undang ini menghendaki adanya suatu undang-undang tentang Ketentuan-ketentuan Pokok Kekuasaan Kehakiman. ${ }^{27}$ UU No. 6 Tahun 1969 merupakan batu pijakan bagi lahirnya kekuasaan kehakiman di Indonesia, dimana kemudian pada tanggal 17 Desember 1970 disahkan UU No. 14 Tahun 1974 tentang Ketentuan-ketentuan Pokok Kekuasaan Kehakiman. Berdasarkan undang-undang ini, Peradilan Agama di Indonesia diakui sebagai pelaku kekuasaan kehakiman, disamping peradilan umum, Peradilan Tata Usaha Negara dan peradilan militer. ${ }^{28}$ Dengan demikian, eksistensi Peradilan Agama semakin kokoh. Pembenahan terhadap kompetensi Peradilan Agama pun dilakukan, diantaranya melalui Undang-undang Nomor 1 Tahun 1974 tentang Perkawinan dan Peraturan Pemerintah Nomor 9 Tahun 1975 tentang Peraturan Pelaksanaan Undang-undang Nomor 1 Tahun 1974 tentang Perkawinan yang mulai berlaku efektif pada tanggal 1 Oktober 1975. Selain itu juga ada Peraturan Pemerintah Nomor 28 Tahun 1977 tentang Perwakafan Hak Milik beserta Peraturan Pelaksanaannya. Kemudian pada tahun 1982 Pemerintah melalui Kepu-

27 Penjelasan Umum UU No. 6 tahun 1969 tentang Pernyataan Tidak Berlakunya Berbagai Undang-Undang Dan Peraturan Pemerintah Pengganti Undang-Undang

28 Lihat Pasal 10 ayat (1) UU No. 14 Tahun 1974 tentang Ketentuan-ketentuan Pokok Kekuasaan Kehakiman 
tusan Menteri Agama Nomor 95 Tahun 1982, membentuk beberapa Pengadilan Tinggi Agama dan Pengadilan Agama untuk Indonesia Tengah dan Timur, seperti Nusa Tenggara Timur, Timor Timur, Sulawesi, Maluku dan Irian Jaya, kemudian disusul daerah-daerah lainnya.

Tonggak sejarah Peradilan Agama yang mempunyai hukum acaranya sendiri dimulai sejak tahun 1989 melalui UU No. 7 tahun 1989 tentang peradilan agama, sekalipun hukum acara yang khusus berlaku di peradilan agama masih sebatas hukum acara dalam bidang hukum keluarga, khususnya perkawinan, sisanya masih menggunakan sumber hukum lama seperti HIR, Rbg29. Namun demikian, paling tidak Peradilan Agama akhirnya mempunyai posisi yang kuat dalam sistem kekuasaan kehakiman, karena ia mempunyai hukum acara untuk menegakkan hukum materiilnya.

Pembangunan hukum terus dilakukan dalam sistem kekuasaan kehakiman untuk melaksanakan amanat UUD 1945 yaitu kekuasaan kehakiman yang merdeka. Untuk terpenuhinya hal tersebut, maka dilakukan perbaikan dan perubahan atas Pasal 11 Undang-undang Nomor 14 Tahun 1970 tentang Ketentuan-ketentuan Pokok Kekuasaan Kehakiman dengan diundangkannya Undang-undang Nomor 35 Tahun 1999 tetang Perubahan Undang-undang Nomor 14 Ttahun 1970 tentang Ketentuan-ketentuan Pokok Kekuasaan Kehakiman pada tanggal 30 Juli 1999. Dengan demikian, pembinaan terhadap Badan Peradilan Agama, juga Badan Peradilan-peradilan lainnya, baik yang menyangkut teknis maupun organisasi, administrasi dan keuangannya dilakukan oleh Makamah Agung RI.

Pemisahan kekuasaan Eksekutif dan Yudikatif (Departemen Agama bagi Peradilan Agama) yang diatur dan dikehendaki oleh Undang-undang Nomor 35 Tahun 1999 tersebut, dimaksudkan untuk memantapkan eksistensi Peradilan Agama pada segi-segi hukum formal dan teknis peradilan sehingga terwujud Kekuasaan Kehakiman yang

29 Lihat pasal 54 UU No. 7 tahun 1989 tentang peradilan agama

30 Pada tahun 2009 disahkan UU No. 48 tahun 2009 tentang kekuasaan Kehakiman yang menggantikan UU No. 4 Tahun merdeka dengan terselenggaranya peradilan yang bebas dari pengaruh dan intervensi kekuasaan Eksekutif. Realisasi terlepasnya kekuasaan Eksekutif atas lembaga kekuasaan kehakiman di bidang pembinaan; organisasi, administrasi dan finansial akhirnya terwujud melalui Undangundang Nomor 4 Tahun 2004 tentang kekuasaan Kehakiman yang ditindaklanjuti dengan Keputusan Presiden Nomor 21 Tahun 2004. Dengan demikian, pembinaan; organisasi, administrasi dan finansial Peradilan Agama dan lembaga peradilan lainnya berada di bawah kekuasaan Mahkamah Agung.

Kemudian pada tahun 2006 disahkan Undang-undang Nomor 3 Tahun 2006 tentang perubahan atas Undang-undang Nomor 7 Tahun 1989 tentang Peradilan Agama. Perubahan atas UU No. 7 Tahun 1989 dilatarbelakangi oleh perkembangan pesat sistem ekonomi syariah di masyarakat yang ditandai dengan menjamurnya kegiatan-kegiatan usaha dengan prinsip syariah. Perkembangan ini berimplikasi pada pola penyelesaian sengketanya, khsusnya di pengadilan, mengingat penyelesaian sengketa ekonomi syariah belum diatur dalam UU No. 7 Tahun 1989 tentang Peradilan Agama. Oleh karenanya perubahan terhadap undang-undang tersebut melalui UU No. 3 tahun 2006 dan untuk menyesuaikan dengan uu kekuasaan kehakiman ${ }^{30}$, undang-undang peradilan Agama diperbaharui lagi pada tahun 2009 melalui UU No. 50 tahun 2009.

Secara normatif, melalui perubahan undang-undang Peradilan Agama yang telah dilakukan telah tegas bahwa Peradilan Agama adalah peradilan bagi orang-orang yang beragama Islam untuk menyelesaikan sengketa perkara tertentu, termasuk tentang perkawinan, waris, wasiat, hibah, wakaf, zakat, infaq, shadaqah, dan ekonomi syariah. Ini lah prinsip personalitas Keislaman yang hanya melekat pada Peradilan Agama. Memang terdapat pengecualian terhadapnya sebagaimana diatur dalam Pasal 50 ayat (1) UU No. 3 Tahun 2006, bahwa dalam hal terjadi sengketa

2004, sebagai akibat perubahan dalam kehidupan ketatanegaraan, khususnya dalam bidang kekuasaan kehakiman sebagai akibat aman-demen UUD 1945. 
hak milik atau sengketa lain dalam perkara yang jadi kewenangan Peradilan Agama, khusus mengenai objek sengketa tersebut harus diputus lebih dahulu oleh pengadilan dalam lingkungan Peradilan Umum. Namun pengecualian ini pun dibatasi dalam ayat (2) yang menegaskan bahwa sepanjang sengketa hak milik tersebut dalam ayat (1) terjadi antara orang-orang yang beragama Islam, maka tetap diselesaikan di Peradilan Agama. Hal ini menghindari upaya memperlambat atau mengulur waktu penyelesaian sengketa karena alasan adanya sengketa milik atau keperdataan lainnya tersebut sering dibuat oleh pihak yang merasa dirugikan dengan adanya gugatan di Pengadilan Agama.

Dengan demikian, jelas sudah bahwa personalitas keislaman melekat pada agama islam yang melekat pada subyek hukum dalam Peradilan Agama. Subyek hukum peradilan Agama berupa orang, bisa dilihat pada Kartu Tanda Penduduk pada kolom agama, sepanjang ia beragama Islam maka sengketanya menjadi kewenangan Peradilan Agama. Sedangkan bagi subyek hukum berupa badan hukum, maka ia dianggap "beragama Islam" sepanjang ia menundukkan diri ${ }^{31}$ pada $\mathrm{Hu}$ kum Islam. Hal ini bisa dilihat dari anggaran dasarnya dan atau hubungan hukum yang dilakukan ketika menjalankan praktik ekonomi syariah.

Oleh karena itu, polemik perebutan kompetensi peradilan yang biasa terjadi antara Peradilan Umum dan Peradilan Agama sebenarnya sudah tidak relevan lagi untuk terjadi dan diperdebatkan. Munculnya ketidakpastian hukum mengenai kompetensi Peradilan Agama disebabkan oleh ketidak legowoan pemangku kebijakan untuk menyerahkan persoalan umat muslim kepada Peradilan Agama. Sebagai contoh, kekisruhan siapa yang berwenang melaksanakan atau membatalkan putusan Badan Arbitrase Syariah Nasional, apakah Peradilan Agama (Pasal 49 UU No. 3 Tahun

31 Penjelasan pasal 49

32 Titik Triwulan Tutik, "Pengawasan Hakim Konstitusi dalam Sistem Pengawasan Hakim Menurut Undang-undang Dasar Negara RI 1945", Jurnal Dinamika Hukum, Vol. 12 No. 3, 2012, hlm. 299

33 Fence M Wantu, "Mewujudkan Kepastian hukum, Keadilan dan kemanfaatan dalam Putusan Hakim di Peradilan Perdata", Jurnal Dinamika Hukum, Vol 12 No. 2, 2012, hlm. 481.
2006) atau peradilan Umum (Pasal 59 ayat (3) UU No. 48 tahun 2009). Sebagaimana diketahui Mahkamah Agung mengeluarkan Surat Edaran Mahkamah Agung No. 8 Tahun 2010 yang menyatakan bahwa Peradilan Umumlah yang berwenang melaksanakan dan/atau membatalkan Putusan badan Arbitrase Syariah Nasional. Munculnya surat edaran ini pada akhirnya menimbulkan ketidakpastian hukum mengenai personalitas keislaman yang merupakan kompetensi Peradilan agama. Bukankah ada prinsip-prinsip hukum yang harus dipegang, ketika terjadi benturan aturan? Surat edaran tersebut juga telah menghancurkan teori peraturan perundang-undangan. Bukankah ada prinsip preferensi dalam menguji keberlakuan suatu undang-undang? Surat edaran tersebut juga telah merusak prinsip kekuasaan kehakiman. Bukankah hakim sebagai pengadil melekat pada dirinya prinsip independensi? Dimana ia bebas dari intervensi mana pun dalam menjatuhkan putusannya, ${ }^{32}$ bahkan termasuk dari Mahkamah Agung sebagai tempat bernaung hakim. Bukankah hakim sebagai pengadil dituntut cerdas dan arif dalam memutus, bahkan ketika terdapat benturan aturan. Persoalan-persoalan tersebut seharusnya dipertimbangkan pula oleh pemangku kebijakan dalam membuat suatu keputusan. Sehingga pada gilirannya keputusan yang diambil bukanlah perbuatan yang sewenang-wenang. Kondisi ini kontradiktif, mengingat hakim dalam menjatuhkan putusan harus mendasarkan pada kepastian hukum. ${ }^{33}$

Oleh karenanya perlu dipertegas lagi bahwa Agama Islam dan Hukum Islam selalu berjalan beriringan. ${ }^{34}$ Hal ini disebabkan, Hukum Islam merupakan hukum yang hidup dan inheren dalam kehidupan umat Islam. ${ }^{35}$ Eksistensi lembaga Peradilan Agama merupakan wujud semakin diterimanya ajaran agama oleh umat manusia. Jabatan Hakim dalam Peradilan Islam merupakan keleng-

34 M. Daud Ali, "Undang-undang Peradilan Agama”, Panji Masyarakat, Nomor 634, tanggal 1-10 Januari 1990, Jakarta, hlm. 71.

35 Abd. Shomad, Dinamisasi Penormaan hukum islam", Perspektif, Vol 15 No. 2, 2010, hlm. 9; Abd. Shomad, "Tajdid Pada Akad Pembiayaan Murabahah di Bank Syariah", Masalah-masalah Hukum, Vol. 40 No. 1, 2011, hlm. 1 
kapan pelaksanaan syariat Islam, sedangkan peradilannya itu sendiri merupakan suatu kewajian kolektif (fardlu kifayah), yakni sesuatu yang dapat ada dan harus dilakukan dalam keadaan bagaimana pun juga. ${ }^{36}$ Oleh karenanya bagi orang yang beragama Islam berlakulah hukum Islam dan menjadi kewenangan Peradilan Agama. Inilah yang kemudian disebut sebagai Prinsip Personalitas Keislaman. Pihak yang tunduk dan dapat ditundukkan kepada kekuasaan di lingkungan Peradilan Agama adalah mereka yang beragama Islam. ${ }^{37}$ Keislaman seseoranglah yang menjadi dasar kewenangan pengadilan di lingkungan Peradilan Agama tanpa memandang derajat keimanannya.

Berdasarkan pada penjelasan diatas, maka jelas bahwa perkembangan kompetensi Peradilan Agama berbanding lurus dengan persoalan kehidupan umat Islam. ${ }^{38}$ Namun, karena Indonesia bukan negara Islam, maka kompetensi Peradilan Agama tidak menyangkut seluruh persoalan umat Islam, melainkan hanya terkait dengan persoalan hukum keluarga (ahwal al-syakhsiyah) ditambah sedikit persoalan muamalah (sebagaimana diatur dalam pasal 49 UU No. 3 Tahun 2006).

Dengan demikian, penambahan kewenangan Peradilan Agama adalah sesuai dengan perkembangan hukum dan kebutuhan hukum masyarakat, khususnya masyarakat muslim. Hal ini sesuai dengan apa yang disampaikan oleh Eugien Ehrlich bahwa "...hukum yang baik adalah hukum yang sesuai dengan hukum yang hidup di masyarakat". ${ }^{39}$ Hukum positif hanya akan efektif apabila selaras dengan hukum yang hidup dalam masyarakat, dalam istilah antropologi dikenal sebagai pola-pola kebudayaan (culture pattern). David N. Schiff menyatakan “...hukum dan peraturan saling interelasi, terutama terlihat jelas dari adanya perubahan-perubahan sosial yang terjadi dengan sangat cepat, sehingga kepentingan individu da-

36 Zaini Ahmad Noeh dan Abdul Basit Adnan, Sejarah Singkat Peradilan Agama Islam di Indonesia, Bina Ilmu, Surabaya, 1983, hlm. 29.

37 Etika Rahmawati, "Telaah terhadap Asas Perso-nalitas Keislaman Dikaitkan dengan Teori Receptio in Complexu", Gloria Yuris, Vol. 1 No. 2, 2013, hlm. 24

38 Rahadi Wasi Bintoro, Abd. Shomad, Masruhan, "Islamic personalization as The Basis of Right Claim Submission in lam masyarakat harus diakomodasi dalam aturanaturan hukum.” Ia juga menyatakan bahwa “...ada hubungan antara berbagai pola perilaku yang menjelma ke dalam bentuk hukum dengan perilaku nyata dari individu". Oleh karena itu, dalam perspektif sosiologi hukum, maka tidak mengherankan jika Peradilan Agama diperluas kewenangan absolutnya, mengingat harus ada kesinambungan yang simetris antara perkembangan masyarakat dengan pengaturan hukum, agar tidak ada gap antara persoalan (problem) dengan cara dan tempat penyelesaiannya (solving). ${ }^{40}$ Perluasan kompetensi Peradilan Agama juga sesuai dengan teori three elements law system Friedman, terutama tentang legal substance. Friedman menyatakan; legal substance adalah aturan, norma, dan pola perilaku nyata manusia yang berada dalam sebuah sistem. Substansi merupakan produk yang dihasilkan, mencakup keputusan yang dikeluarkan, termasuk dalam pengertian substansi adalah aturan baru yang disusun. Substansi melingkupi living law (hukum yang hidup), tidak hanya aturan yang ada dalam kitab undang-undang atau law in books. Dengan demikian, perluasan kompetensi Peradilan Agama merupakan sebuah keniscayaan, mengingat semua yang menjadi wewenang Peradilan Agama, baik menyangkut tentang perkawinan, waris, wakaf, zakat, sampai pada masalah ekonomi syariah, merupakan sesuatu yang telah melekat pada masyarakat muslim. Dengan kata lain, hukum Islam yang menjadi kompetensi Peradilan Agama selama ini, telah menjadi living law, hukum yang hidup dan diamalkan oleh masyarakat.

\section{PENUTUP}

Eksistensi Peradilan Agama sebagai Peradilan Islam telah ada sejak agama Islam masuk dan berkembang di Indonesia. Perkembangan Peradilan Agama selalu berbanding lurus dengan kebu-

Religious Court", Jurnal Dinamika Hu-kum, Vol. 17 No. 2, 2017, hlm. 192

39 Soerjono Soekanto, Perspektif Teoritis Studi Hukum dalam Masyarakat, Rajawali, Jakarta 1985, hlm. 19.

40 Adam Podgorecki dan Christopher J. Whelan "Sociological Approaches to Law", terjemahan. Rnc. Widyaningsih dan Kartasapoetra, Pendekatan Sosio-logis Terhadap Hukum, Bina Aksara, Jakarta, 1987, hlm. 253-287. 
tuhan umat muslim dan political will "penguasa" di negeri ini. Ciri khas Peradilan Agama adalah subyek hukum yang beragama Islam atau penundukan diri terhadap agama Islam. Inilah prinsip personalitas yang hanya dimiliki oleh Peradilan Agama sebagai kompetensi absolutnya. Penambahan kompetensi Peradilan Agama merupakan suatu keniscayaan dari dinamika hukum Islam yang diterapkan oleh umat muslim, karena ia adalah the living law.

Dengan demikian, sepanjang subyek hukumnya beragama Islam atau menundukan diri terhadap agama Islam, maka sengketa yang terjadi merupakan kompetensi absolut Peradilan Agama. Adapun "Perebutan kompetensi” yang sementara ini terjadi harus dikembalikan pada prinsip-prinsip hukum.

\section{DAFTAR PUSTAKA}

Ahmad R. "Peradilan Agama di Indonesia”. Yudisia. Vol. 6 No. 2. 2015. Pp. 311-339;

Ahmad. "Penyelesaian Sengketa Ekonomi Syariah di Pengadilan Agama”. Jurnal Ius. Vol. 2 No. 6. Desember 2014. Pp. 476-488;

Ali, M. Daud. "Undang-undang Peradilan Agama”. Panji Masyarakat. Nomor 634. tanggal 1-10 Januari 1990. Jakarta;

ASA. 1989. Sejarah Peradilan Agama. Serial Media Dakwah. Jakarta.

Assaad, A.Sukmawati. "Teori Pemberlakuan $\mathrm{Hu}$ kum Islamdi Indonesia”. Jurnal Al Ahkam. Vol. IV No. 2. Agustus 2014;

Asutay, Mehmet. "Conceptualisation of The Second Best Solution in Overcoming The Social Failure of Islamic Banking And Finance: Examining The Overpowering of Homoislamicus By Homoeconomicus". IIUM Journal of Economics and Managemen. Vol. 15. No. 2. 2007. The International Islamic University Malaysia. PP: 167-195;

Bintoro, Rahadi Wasi.. Abd. Shomad. dan Masruhan. "Islamic personalization as The Basis of Right Claim Submission in Religious Court”. Jurnal Dinamika Hukum. Vol. 17 No. 2. 2017. Pp. $188-194$. DOI: 10.20884/1.jdh.2017.17.2.899;

Departemen Agama RI. Laporan Bagian Proyek Penelitin Yusisprodensi Peradilan Agama.
Proyek Peningkatan Penelitian/ Survey Keagamaan. Jakarta: 1971/1972;

Hamka. 1981Sejarah Umat Islam. Jilid III. Bulan Bintang. Jakarta;

Hassan, M. Kabir and Abdel-Hameed M. Bashir. "Determinants of Islamic Banking Profitability". Papers. 10th ERF Annual Conference. Morocco. 2003. Dikutip dari Laman: http://nzibo.com/IB2/Determinants. pdf. diakses pada tanggal 11 Desember 2014;

Iqbal, Munawar And Philip Molyneux. "Thirty Years Of Islamic Banking:History. Performance And Prospects". Reviewed by: Abdelkader Chachi. Islamic Economics Research Centre King Abdulaziz University. Jeddah. Saudi Arabia. J.KAU: Islamic Econ.. Vol. 19. No. 1. pp: 37-39;

Lindsey, Tim. "Between Piety and Prudence: State Syariah and the Regulation of Islamic Banking in Indonesia". Sydney Law Review. Vol. 34 No. 107. 2012. Pp. 107-127;

Mansyur, Ali. "Aspek Hukum Perbankan Syariah dan Implementasinya di Indonesia". Jurnal Dinamika Hukum. Vol. 11 Edisi khusus. 2011. Pp. 68-75. DOI: 10.20884/1.jdh.2011.11.Edsus.263;

Mardani. "Kedudukan Hukum Islam dalam Sistem hukum Nasional". Jurnal Hukum. Vol. 16 No. 2. April 2009. Pp. 267-287;

Matrais, Sumadi. "Kemandirian Peradilan Agama dalam Perspektif Undang-undang Peradilan Agama". IUSTUM. No. 1 Vol. 15. Januari 2008. h. 121-144

Muhammad Syafi'i Antonio. "Membangun Ekonomi Islam di Indonesia". Varia Peradilan. Tahun XXI No. 245 April 2006. Jakarta: IKAHI;

Noeh, Zaini Ahmad dan Abdul Basit Adnan. 1983. Sejarah Singkat Peradilan Agama Islam di Indonesia. Bina Ilmu. Surabaya.;

Pardede, Marulak. Eksistensi dan Kedudukan $\mathrm{Hu}$ kum Peradilan Agama Dalam Tata Hukum Indonesia. Angkatan Bersenjata. Jakarta. 24 Agustus 1989.

Podgorecki, Adam dan Christopher J. Whelan. 1987. "Sociological Approaches to Law". terj. Rnc. Widyaningsih dan Kartasapoetra. Pendekatan Sosiologis Terhadap Hukum. Bina Aksara. Jakarta.;

Rahmawati, Etika. "Telaah terhadap Asas Personalitas Keislaman Dikaitkan dengan Teori Receptio in Complexu". Gloria Yuris. Vol. 1 
No. 2013. Tersedia di: http://jurnal.untan.ac.id/index.php/jmfh/ article/view/1593;

Shomad, Abd. "Dinamisasi Penormaan hukum islam". Perspektif. Vol 15 No. 2. 2010. Pp. 99-122;

Shomad, Abd. "Tajdid Pada Akad Pembiayaan Murabahah di Bank Syariah". Masalahmasalah Hukum. Vol. 40 No. 1. 2011. Pp. 19. DOI: 10.14710/mmh.40.1.2011.1-9;

Soekanto, Soerjono. 1985. Perspektif Teoritis Studi Hukum dalam Masyarakat. Rajawali. Jakarta;

Suma, Muhammad Amin. 2004. Himpunan Undang-undang Perdata Islam dan Peraturan Pelaksanan Lainnya di Negara Hukum Indonesia. Rajawali Press. Jakarta.;

Thalib, Sayuti. 1985. Receptio A Contrario. Bina Aksara. Jakarta.;

Titik Triwulan Tutik. "Pengawasan Hakim Konstitusi dalam Sistem Pengawasan Hakim Menurut Undang-undang Dasar Negara RI 1945”. Jurnal Dinamika Hukum. Vol. 12 No. 2. 2012. Pp. 295-311. DOI: 10.20884/1.jdh.2012.12.2.51;

Wantu; Fence M. "Mewujudkan Kepastian hukum. Keadilan dan kemanfaatan dalam Putusan Hakim di Peradilan Perdata". Jurnal Dinamika Hukum. Vol 12 No. 2. 2012. Pp: 490506. DOI: 10.20884/1.jdh.2012.12.3.122;

Zaman, M. Raquibuz and Hormoz Movassaghi. Islamic Banking A Performance Analysis ". The Journal of Global Business . Vol. 12. No. 22. Spring 2001. Pp. 31-38. 
28 Pena Justisia: Media Komunikasi dan Kajian Hukum Vol. 17, No. 2, 2017 